\title{
塩素含量の異なるトウモロコシサイレージ給与が 乾乳牛のミネラル出納に及ぼす影響
}

\author{
神谷裕子 ${ }^{1} \cdot$ 加藤直樹 $^{1} \cdot$ 服部育男 ${ }^{1} \cdot$ 野中最子 $^{1} \cdot$ 丹中正仁 ${ }^{1}$ \\ 1農業・食品産業技術総合研究機構九州沖縄農業研究センター, 合志市 861-1192
}

(2014. 12. 16 受付, 2015. 6. 16 受理)

\begin{abstract}
要＼cjkstart約＼cjkstart塩素 $(\mathrm{Cl})$ 含量の違いによりカチオンアニオンバランス (DCAD) 値の異なるトウモロコシサイレー ジの給与が, ミネラル出納に及ぼす影響を検討するために, 非妊娠乾乳牛 4 頭を供試して, クロスオーバー 法による飼養試験を行った. トウモロコシは, カリウム $(K)$ および窒素肥料において, 塩素系 (低 DCAD 区) または硫酸系肥料 (高 DCAD 区) を用いて栽培した. トウモロコシサイレージの Cl 今量は低 DCAD 区で 5.3 $\mathrm{g} / \mathrm{kg}$, 高 DCAD 区で $3.5 \mathrm{~g} / \mathrm{kg}$ であったが, K, ナトリウム (Na) および硫黄（S）含量には大きな差は認 められなかった. トウモロコシサイレージの DCAD 值は, 低 DCAD 区で $195.1 \mathrm{mEq} / \mathrm{kg}$, 高 DCAD 区で $267.8 \mathrm{mEq} / \mathrm{kg}$ であった. 低 DCAD 区では, 高 DCAD 区と比較し, Cl 摃取量および腸管での吸収量が有 意に $(P<0.01)$ 增加した. 腸管での $\mathrm{K}, \mathrm{Na}, \mathrm{S}$ 吸収量には, 両区で有意な差は認められなかった. 尿 $\mathrm{pH}$ は低 DCAD 区で 8.06, 高 DCAD 区で 8.22 であり, 低 DCAD 区で有意に $(P<0.05)$ 低かった. 尿中へ の Ca 排泄量は，低 DCAD 区で有意に $(P<0.01)$ 増加した。
\end{abstract}

日本畜産学会報 86 (4), 449-455, 2015

キーワード: 塩素, DCAD, トウモロコシサイレージ, 乳牛, ミネラル出納

分娩前後の乳牛における低カルシウム $(\mathrm{Ca})$ 血症は, 泌乳開始に伴う乳中へのCaの急激な分泌にミネラル代謝 が適応できず, 血漿中 Ca 濃度が低下することが原因で起 こる. 低 Ca 血症は, 胎盤停滞, 第 4 胃変位やケトーシス 等の周産期疾患を誘発することが多く, その後の乳生産性 も大幅に低下させることから, 経済的な損失が大きく問題 である (Goff と Horst 1997).

低 Ca 血症を予防する方法の一つとして, 分娩前の飼料 中カチオンアニオンバランス (DCAD) を低下させ, ウシ を緩やかな代謝性アシドーシスとし, 分娩時の Ca 代謝を 改善させる方法が行われている (Horst 51997 ; Goff 5 2004). 飼料中 DCAD 值を低下させるためには，一般的 に陰イオン塩を飼料に添加することが行われており, 効果 は認められているが, 啫好性の面で飼料摂取量を低下させ る場合があることも報告されている (Vagnoni と Oetzel 1998 ; Charbonneau 5 2006). 一方, 粗飼料中 DCAD 值を制御することによっても給与飼料の DCAD 值を低下 できることが知られており，このためには粗飼料中のカリ ウム $(\mathrm{K})$, ナトリウム $(\mathrm{Na})$ 含量を低下させ, 塩素 $(\mathrm{Cl})$, 硫黄 $(S)$ 含量を増加させることが必要となる. 最近, 塩化 Ca や塩化アンモニウムを施肥することで, チモシ一やア ルファルファにおいて Cl 含量を増加させ得ることが報告 された (Goff 52007 ; Pelletier 52007 ; Charbonneau
ら 2009)。また, 硫酸系肥料の代替として塩素系肥料を 用いることで, チモシーおよびオーチャードグラスにおい

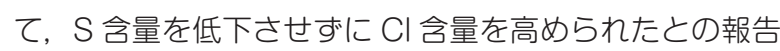
もある (佐藤ら 2010). さらにCl 含量を高めるなどして DCAD 值を低くしたチモシー乾草またはサイレージを乳 牛に給与すると, 陰イオン塩を添加した場合と同様の効果 が得られることも報告されている(Heron 5 2009)。こ のことから, Cl 今量を高めた低 DCAD 粗飼料は, 分娩前 後の低 Ca 血症予防に適した飼料になると考えられる.

自給粗飼料の中でトウモロコシサイレージは栄養価が高 $<$, 乾物摂取量の低下しやすい周産期の乳牛に適した粗飼 料であると考えられる. しかしながら, 塩素系肥料を施用 して栽培したトウモロコシのサイレージ給与が, 乳牛のミ ネラル代謝に及ぼす影響については検討がなされていな い. そこで, Cl含量を高めたトウモロコシを栽培し, 乾 乳牛に給与して, ミネラル出納に及ぼす影響を検討した。

\section{材料および方法}

\section{1. トゥモロコシサイレージの栽培・調製}

供試したトウモロコシ (Zea Mays, 品種:34B39) は, 九州沖縄農業研究セン夕ー (熊本県合志市) の圃場で, 2011 年 4 月 3 日に条間 $75 \mathrm{~cm}$, 株間 $20 \mathrm{~cm}$ で播種し, 8 月 8 日に黄熟期で収穫し，細断型ロールベーラ（TSB0910；

連絡者：神谷裕子（fax：096-249-1002, e-mail : yukoiwm@affrc.go.jp） 
IHIスター, 北海道) を利用してサイしージ調製した. 施肥 として, 塩安, 塩化カリなどの塩素系肥料を用いての栽培 (低 DCAD 区) と硫安, 硫酸カリなどの硫酸系肥料を用い ての栽培 (高 DCAD 区) を設定した. 低DCAD 区では窒 素肥料に塩安 (主成分 $\mathrm{NH}_{4} \mathrm{Cl}, \mathrm{N}$ 含有率 25\%), カリウム 肥料に塩化カリ（主成分 $\mathrm{KCl}, \mathrm{K}_{2} \mathrm{O}$ 含有率 $60 \%$ ）を使用 し, 高 DCAD 区では窒素肥料に硫安 (主成分 $\left(\mathrm{NH}_{4}\right)_{2} \mathrm{SO}_{4}$, $\mathrm{N}$ 今有率 $21 \%$ ), カリウム肥料に硫酸カリ (主成分 $\mathrm{K}_{2} \mathrm{SO}_{4}$, $\mathrm{K}_{2} \mathrm{O}$ 含有率 $50 \%$ ）を使用した. リン酸肥料には両試験区 とも溶リン（主成分をリン酸とする混合物, $\mathrm{P}_{2} \mathrm{O}_{5}$ 含有率 $20 \%$ ）を用いた. 両試験区とも $\mathrm{N}, \mathrm{P}_{2} \mathrm{O}_{5}, \mathrm{~K}_{2} \mathrm{O}$ の各成分施 肥量が $150 \mathrm{~kg} / \mathrm{ha}$ となるように設定した. リン酸肥料お よびカリウム肥料は全量基肥で播種前に施用し, 窒素肥料 は $2 / 3$ を基肥として, 残り $1 / 3$ を追肥として生育初期に 施用した. 実際の施用量は低 DCAD 区では基肥として塩 安 $400 \mathrm{~kg} / \mathrm{ha}$, 塩化カリ $250 \mathrm{~kg} / \mathrm{ha}$, 溶リン $750 \mathrm{~kg} / \mathrm{ha}$, 追肥として塩安 $200 \mathrm{~kg} / \mathrm{ha}$, 高 DCAD 区では基肥として 硫安 $480 \mathrm{~kg} / \mathrm{ha}$, 硫酸カリ $300 \mathrm{~kg} / \mathrm{ha}$, 溶リン $750 \mathrm{~kg} /$ ha, 追肥として硫安 $240 \mathrm{~kg} / \mathrm{ha}$ であった.

\section{DCAD 值の異なるトウモロコシサイレージの乾乳 牛への給与試験}

ホルスタイン種非妊娠乾乳牛 4 頭を供試し, 高 DCAD 区トウモロコシサイレージまたは, 低 DCAD 区トウモ口 コシサイレージを給与する 1 期 14 日間（予備期 9 日間, 本試験期 5 日間) の出納試験を, クロスオーバ一法により 行つた. 試験中, 供試牛は䔬尿分離機を備えた個別スト一
ルに繋養した，給与飼料は，日本飼養標準・乳牛（農業・ 食品産業技術総合研究機構 2006）における成雌牛の維持 要求量を満たす量とし, $8: 30$ および $16: 00$ の 2 回に分 けて給与した. また, 濃厚飼料として飼料全体の粗タンパ ク質 (CP) 含量が約 12\%となるよう大豆粕を, Ca 摂取 量が要求量を満たすように炭酸 Ca を, 飼料全体の食塩含 量が 0.25\%となるように食塩を給与した. トウモロコシ サイレージの給与量は原物で $21.0 \mathrm{~kg}$, 濃厚飼料給与量は 原物で $1.1 \mathrm{~kg}$ とした. 水は, 自由摂取とした. 給与飼料の 飼料成分は表 1 に示した. 本試験開始時および終了時に, 体重を測定した．本試験中，糞および尿は $10: 30$ に回収 した. 蕒および尿サンプルは重量ベースで一定割合を，そ の都度一部を採取し, 分析まで泠蔵保存した. さらに飼料 および䔬サンプルの一部は通風乾燥機で乾燥 $\left(55^{\circ} \mathrm{C}, 48\right.$ 時 間), 粉砕し (メッシュ見開き $1 \mathrm{~mm}, \mathrm{P} 15$; FROTSCH, Idar-Oberstein, Germany), 分析に供した. 本試験 3, 4, 5日目の 9:30に部分尿を採取し, 直ちに $\mathrm{pH}$ を測定し た (PH71; 横河電気, 東京)。本試験終了曰の $10: 30$ に 頸静脈から採血を行い, 遠心分離 $\left(1500 \times g, 15\right.$ 分, $\left.4^{\circ} \mathrm{C}\right)$ 後, 血漿を-20ㄷで泠凍保存し分析に供した.

本試験は，九州沖縄農業研究センタ一動物実験要領に基 づいて設置された動物実験委員会の承認の下に行われた.

\section{3. 試料分析}

飼料中の水分, CP, 粗脂肪, 中性デタージェント䋊維, 酸性デタージェント繊維を, 常法に従し測定した（自給飼 料利用研究会 2009). 飼料中, 糞中および尿中の K, Na, Ca

Table 1 Chemical composition of experimental diets

\begin{tabular}{|c|c|c|c|c|c|}
\hline & \multicolumn{2}{|c|}{ Corn silage } & \multirow[t]{2}{*}{ Concentrate ${ }^{1)}$} & \multicolumn{2}{|c|}{ Expermental Feed ${ }^{21}$} \\
\hline & High DCAD & Low DCAD & & High DCAD & Low DCAD \\
\hline DM \% & 32.6 & 31.5 & 93.3 & 35.6 & 34.6 \\
\hline CP (DM\%) & 7.6 & 7.6 & 48.3 & 12.9 & 13.1 \\
\hline EE (\%DM) & 3.8 & 3.8 & 1.2 & 3.5 & 3.5 \\
\hline NDFom (\%DM) & 43.3 & 42.9 & 11.2 & 39.1 & 38.6 \\
\hline ADFom (\%DM) & 25.2 & 24.4 & 8.7 & 23.0 & 22.3 \\
\hline $\mathrm{DCAD}^{3)} \mathrm{mEq} / \mathrm{kg} \mathrm{DM}$ & 267.8 & 195.1 & 428.0 & 288.7 & 226.4 \\
\hline $\mathrm{K}(\mathrm{g} / \mathrm{kg} \mathrm{DM})$ & 16.6 & 15.8 & 26.0 & 17.9 & 17.2 \\
\hline $\mathrm{Na}(\mathrm{g} / \mathrm{kg} \mathrm{DM})$ & 0.2 & 0.1 & 8.6 & 1.3 & 1.3 \\
\hline $\mathrm{Cl}$ (g/kg DM) & 3.5 & 5.3 & 13.1 & 4.7 & 6.3 \\
\hline $\mathrm{S}(\mathrm{g} / \mathrm{kg} \mathrm{DM})$ & 1.1 & 1.1 & 3.9 & 1.5 & 1.5 \\
\hline $\mathrm{Ca}$ (g/kg DM) & 1.4 & 1.6 & 15.3 & 3.2 & 3.4 \\
\hline $\mathrm{P}(\mathrm{g} / \mathrm{kg} \mathrm{DM})$ & 2.3 & 2.1 & 7.5 & 3.0 & 2.8 \\
\hline Mg (g/kg DM) & 1.3 & 1.3 & 2.6 & 1.5 & 1.5 \\
\hline
\end{tabular}

DM : dry matter, CP : crude protein, EE : ether extract, NDFom : neutral detergent fiber, ADFom : acid detergent fiber, $\mathrm{K}$ : potassium, $\mathrm{Na}$ : sodium, $\mathrm{Cl}$ : chlorine, $\mathrm{S}$ : sulfur, $\mathrm{P}$ : phosphorus, $\mathrm{Ca}$ : calcium, Mg : magnesium

1) Concentrate consists of $94.5 \%$ Soybean meal, 3.5\% Calcium carbonate and $2.0 \%$ Salt.

2) Experimental Feed consists of $21.0 \mathrm{kgFM}$ of corn silage and $1.1 \mathrm{kgFM}$ of concentrate

3) $D C A D \mathrm{mEq} / \mathrm{kg}=\left(\mathrm{Na}^{+}+\mathrm{K}^{+}\right)-\left(\mathrm{Cl}^{-}+\mathrm{S}^{2-}\right)$ 
およびマグネシウム $(\mathrm{Mg})$ の含量は, 試料を硝酸, 過塩素 酸で湿式灰化後, 原子吸光光度計で測定した (伊藤 1975). S 含量は, 試料を湿式灰化後に, ICP-MS（SPS4000； (株) 日立八イテクサイエンス, 東京) を用いて測定した. リン $(P)$ 含量は, 試料を湿式灰化後に比色法 (Gomori

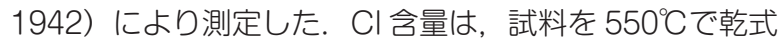
灰化後に, 硝酸銀で滴定して測定した (自給飼料利用研究 会 2009). 血漿中 $\mathrm{K}, \mathrm{Na}, \mathrm{Cl}, \mathrm{Ca}$, 無機 $\mathrm{P}(\mathrm{Pi})$ および Mg 濃度は, 生化学分析装置ドライケム (3500V; 富士フ イルム, 東京) を用いて測定した. 血將中オステオカルシ ン (Gla-OC) 濃度は, 酵素免疫測定法を用いて (Gla type Osteocalcin EIA kit; タカラバイオ(株), 滋賀) で測定した. 血漿中骨 I 型コラーゲンC 末端テロペプチド 分解産物 $(\mathrm{C} T \mathrm{x}$ ) は, 酵素免疫測定法 (フレライザ $\beta$ ク スラプス-N；富士レビオ(株), 東京) を用いて測定した.

データの統計処理については, SAS (1999) GLM プ ロシジャを用いて飼料の効果を分散分析した.

\section{結果}

給与した飼料の成分含有率を表 1 に示した。低 DCAD 区トウモロコシサイレージ（塩素系肥料）のCl含量は $5.3 \mathrm{~g} / \mathrm{kg}$, 高 DCAD 区トウモロコシサイレージ（硫酸系 肥料）のCl含量は $3.5 \mathrm{~g} / \mathrm{kg}$ であり，塩素系肥料の施肥に より, トウモロコシサイレージの Cl 含量は約 1.5 倍と なった. トウモロコシサイレージの S 含量は, 施肥によ る影響を受けなかった。他の成分については, 低 DCAD 区トウモロコシサイレージと高 DCAD 区トウモロコシサ イレージで大きな違いはなかった. 低 DCAD 区トウモ口 コシサイレージの DCAD 值は $195.1 \mathrm{mEq} / \mathrm{kg}$, 高 DCAD 区トウモロコシサイレージの DCAD 值は $267.8 \mathrm{mEq} / \mathrm{kg}$ であった.

トウモロコシサイレージおよび濃厚飼料の乾物摂取量は それぞれ，低DCAD 区で $6.61 \mathrm{~kg}, 1.03 \mathrm{~kg}$, 高 DCAD
区で $6.84 \mathrm{~kg}, 1.03 \mathrm{~kg}$ であった (表 2). 両区ともに, 残飼 は認められなかった，排䔬量は低 DCAD 区で高 DCAD 区と比較し, 有意に $(P<0.05)$ 低かったが, 乾物消化 率は両区で明らかな差が認められなかった（表 2)。排尿 量には, 両区で差は認められなかった。尿中 $\mathrm{pH}$ は, 低 DCAD 区で高 DCAD 区と比較し有意に低くなった（ $P$ $<0.05)$.

表 3 に, K 出納, Na 出納, Cl 出納および $\mathrm{S}$ 出納を示 した. K摂取量は, 低 DCAD 区で高 DCAD 区と比較し 有意に $(P<0.01)$ 低かったが, 糞中および尿中への $K$ 排泄量, $\mathrm{K}$ 吸収量および $\mathrm{K}$ 蓄積量は両区で差が認められ なかった. Na 摂取量は，低 DCAD 区で高 DCAD 区と 比較し有意に $(P<0.01)$ 低かったが, 糞中および尿中 への Na 排泄量, Na 吸収量および Na 蓄積量は両区で差 が認められなかった．Ｃl摂取量は，低 DCAD 区で 48.5 g/day, 高 DCAD 区で $37.4 \mathrm{~g} /$ day であり, 低 DCAD 区 で有意に $(P<0.01)$ 高かった. 䔬中への Cl 排泄量は, 両区で差が認められなかつたが，尿中への Cl 排泄量は高 DCAD 区と比較し低 DCAD 区で高い傾向を示した $(P$ $<0.10)$. 腸管での Cl 吸収量は, 高 DCAD 区で $31.2 \mathrm{~g} /$ day, 低 DCAD 区で $40.1 \mathrm{~g} /$ day であり, 低 DCAD 区で 有意に $(P<0.01)$ 高くなった. Cl 蓄積量は, 両区で差 が認められなかった。供試牛の S 掑取量は, 低DCAD 区 で高 DCAD 区と比較し有意に $(P<0.01)$ 低かったが, 䔬中および尿中への $S$ 排泄量, $S$ 吸収量および $S$ 蓄積量 は両区で差が認められなかった，表 4 に，Ca出納，P出 納およびMg 出納を示した. Ca 摂取量は, 低 DCAD 区 で高 DCAD 区と比較し有意に $(P<0.01)$ 高かった。糞 中への Ca 排泄量は, 両区で差が認められなかつたが, 尿 中への Ca 排泄量は高 DCAD 区と比較し低 DCAD 区で 有意に $(P<0.01)$ 高<なった. 腸管でのCa 吸収量お よび体内 Ca 蓄積量は, 両区で差が認められなかった. P 摂取量は, 低 DCAD 区で高 DCAD 区と比較し, 有意に $(P$

Table 2 Body weight DM intake, feces and urine production and urine $\mathrm{pH}$ of experimental cows

\begin{tabular}{lcclc}
\hline \hline & High DCAD & Low DCAD & SE & Significance \\
\hline BW kg & 588 & 579 & 5 & NS \\
DMI kg & & & & \\
$\quad$ Corn silage & 6.84 & 6.61 & 0.004 & $P<0.01$ \\
$\quad$ Concentrate & 1.03 & 1.03 & 0.0007 & NS \\
Total & 7.87 & 7.64 & 0.005 & $P<0.01$ \\
& & & & \\
Feces kgDM & 2.4 & 2.2 & 0.02 & $P<0.05$ \\
DM digestibility \% & 69.8 & 70.9 & 0.3 & $\mathrm{NS}$ \\
Urine volume kg & 5.9 & 6.6 & 0.7 & $\mathrm{NS}$ \\
Urine pH & 8.22 & 8.06 & 0.02 & $P<0.05$ \\
\hline
\end{tabular}

BW : body weight, DMI : dry matter intake, DM : dry matter

NS : not significant 
神谷 $\cdot$ 加藤 $\cdot$ 服部 $\cdot$ 野中 $\cdot$ 田中

Table 3 Intake, excretion in feces and urine, apprent absorption and retention of $\mathrm{K}, \mathrm{Na}, \mathrm{Cl}$ and $\mathrm{S}$ in cows fed experimental diets

\begin{tabular}{|c|c|c|c|c|}
\hline & High DCAD & Low DCAD & SE & Significance \\
\hline \multicolumn{5}{|l|}{ K balance (g/day) } \\
\hline Intake & 140.6 & 131.3 & 0.08 & $P<0.01$ \\
\hline Feces excretion & 38.6 & 35.4 & 4.5 & NS \\
\hline Apparent absorption & 102.0 & 96.0 & 4.4 & NS \\
\hline Absorption \% intake & 72.6 & 73.1 & 3.3 & NS \\
\hline Urine excretion & 75.0 & 76.8 & 4.2 & NS \\
\hline Retention & 27.0 & 19.2 & 2.6 & NS \\
\hline Retention \% intake & 19.0 & 14.5 & 1.9 & NS \\
\hline \multicolumn{5}{|l|}{ Na balance (g/day) } \\
\hline Intake & 10.3 & 9.8 & 0.01 & $P<0.01$ \\
\hline Feces excretion & 6.5 & 6.0 & 1.0 & NS \\
\hline Apparent absorption & 3.8 & 3.9 & 1.0 & NS \\
\hline Absorption \% intake & 36.1 & 39.5 & 10.0 & NS \\
\hline Urine excretion & 1.9 & 2.5 & 0.6 & NS \\
\hline Retention & 1.8 & 1.4 & 1.5 & NS \\
\hline Retention \% intake & 16.6 & 14.5 & 15.0 & NS \\
\hline \multicolumn{5}{|l|}{$\mathrm{Cl}$ balance (g/day) } \\
\hline Intake & 37.4 & 48.5 & 0.03 & $P<0.01$ \\
\hline Feces excretion & 6.2 & 8.4 & 0.6 & NS \\
\hline Apparent absorption & 31.2 & 40.1 & 0.6 & $P<0.01$ \\
\hline Absorption \% intake & 83.4 & 82.7 & 1.6 & NS \\
\hline Urine excretion & 23.9 & 34.4 & 2.1 & $P<0.10$ \\
\hline Retention & 7.3 & 5.7 & 1.6 & NS \\
\hline Retention \% intake & 19.4 & 11.7 & 3.7 & NS \\
\hline \multicolumn{5}{|l|}{ S balance (g/day) } \\
\hline Intake & 11.4 & 11.1 & 0.01 & $P<0.01$ \\
\hline Feces excretion & 5.9 & 5.6 & 0.1 & NS \\
\hline Apparent absorption & 5.5 & 5.5 & 0.1 & NS \\
\hline Absorption \% intake & 48.4 & 50.0 & 0.6 & NS \\
\hline Urine excretion & 3.4 & 3.4 & 0.1 & NS \\
\hline Retention & 2.1 & 2.1 & 0.01 & NS \\
\hline Retention \% intake & 18.4 & 18.9 & 0.1 & NS \\
\hline
\end{tabular}

$\mathrm{K}$ : potassium, $\mathrm{Na}$ : sodium, $\mathrm{Cl}$ : chlorine, $\mathrm{S}$ : sulfur

NS : not significant

$<0.01)$ 低かった. 鿓中 $P$ 排泄量は, 低 DCAD 区で高 DCAD 区と比較し，低い傾向 $(P<0.10)$ にあった，尿 中 $P$ 排泄量, $P$ 吸収量および $P$ 蓄積量は, 両区で差が認 められなかった. Mg 摂取量は, 低 DCAD 区で高 DCAD 区と比較し，有意に $(P<0.01)$ 低かった，翼中および 尿中への Mg 排泄量, および Mg 蓄積量は, 両区で差が 認められなかった.

血漿中 $\mathrm{Na}, \mathrm{K}, \mathrm{Cl}, \mathrm{Ca}, \mathrm{Pi}$ および $\mathrm{Mg}$ 濃度は, いずれ の値にも両区で有意な差が認められなかった (表 5)。ま た骨形成マーカーである血漿中 Gla-OC 濃度および骨吸 収マーカーである血漿中 CTX 濃度は, 両区において明ら かな差が認められなかった（表5).

\section{考察}

本試験では，DCAD を調整するために，カリウムおよ び窒素の施肥に，塩素系肥料を用いた低 DCAD 区，およ び硫酸系肥料を用いた高 DCAD 区を設けて，トウモロコ シを栽培した. この結果, 低 DCAD 区で高 DCAD 区と 比較し, トウモロコシサイレージの Cl 含量が約 1.5 倍に 高まった，これは，佐藤ら（2010）が，塩素系肥料を施 用したオーチャードグラスおよびチモシーにおいて，Cl 含量が高まったという報告と同様の結果であった.

本試験では，給与した飼料に残飼は認められなかったこ とから, 制限給䬣の条件下ではあるが, トウモロコシサイ 
Table 4 Intake, excretion in feces and urine, apprent absorption and retention of $\mathrm{Ca}, \mathrm{P}$ and $\mathrm{Mg}$ in cows fed experimental diets

\begin{tabular}{lrrrc}
\hline \hline & High DCAD & Low DCAD & SE & Significance \\
\hline Ca balance (g/day) & & & & \\
Intake & 25.6 & 26.4 & 0.02 & $P<0.01$ \\
Feces excretion & 21.1 & 21.6 & 0.4 & $\mathrm{NS}$ \\
Apparent absorption & 4.5 & 4.8 & 0.4 & $\mathrm{NS}$ \\
$\quad$ Absorption \% intake & 17.4 & 18.0 & 1.6 & $\mathrm{NS}$ \\
Urine excretion & 0.3 & 0.5 & 0.01 & $P<0.01$ \\
Retention & 4.2 & 4.3 & 0.4 & $\mathrm{NS}$ \\
$\quad$ Retention \% intake & 16.1 & 16.0 & 1.6 & $\mathrm{NS}$ \\
\hline Palance (g/day) & & & & \\
Intake & 23.4 & 21.3 & 0.01 & $P<0.01$ \\
Feces excretion & 18.6 & 16.9 & 0.3 & $P<0.10$ \\
Apparent absorption & 4.8 & 4.4 & 0.3 & $\mathrm{NS}$ \\
Absorption \% intake & 20.1 & 20.6 & 1.3 & $\mathrm{NS}$ \\
Urine excretion & 0.5 & 0.4 & 0.1 & $\mathrm{NS}$ \\
Retention & 4.4 & 4.0 & 0.3 & $\mathrm{NS}$ \\
Retention \% intake & 18.2 & 18.6 & 1.4 & $\mathrm{NS}$ \\
\hline Mg balance (g/day) & & & & \\
Intake & 11.8 & 11.6 & 0.01 & $P<0.01$ \\
Feces excretion & 7.3 & 6.9 & 0.2 & $\mathrm{NS}$ \\
Apparent absorption & 4.5 & 4.7 & 0.2 & $\mathrm{NS}$ \\
Absorption \% intake & 37.7 & 40.4 & 1.5 & $\mathrm{NS}$ \\
Urine excretion & 2.3 & 2.7 & 0.4 & $\mathrm{NS}$ \\
Retention & 2.2 & 1.9 & 0.5 & $\mathrm{NS}$ \\
Retention \% intake & 18.5 & 16.7 & 4.8 & $\mathrm{NS}$ \\
\hline
\end{tabular}

Ca : calcium, $\mathrm{P}$ : phosphorus, Mg : magnesium

NS : not significant

Table 5 The concentrations of plasma minerals and bone turnover marker of experimental cows

\begin{tabular}{lrrrc}
\hline \hline & High DCAD & Low DCAD & SE & Significance \\
\hline $\mathrm{Na}(\mathrm{mEq} / \mathrm{L})$ & 143.0 & 139.0 & 1.8 & $\mathrm{NS}$ \\
$\mathrm{K}(\mathrm{mEq} / \mathrm{L})$ & 4.5 & 4.6 & 0.1 & $\mathrm{NS}$ \\
$\mathrm{Cl}(\mathrm{mEq} / \mathrm{L})$ & 94.5 & 92.0 & 0.8 & $\mathrm{NS}$ \\
$\mathrm{Ca}(\mathrm{mg} / \mathrm{dL})$ & 11.1 & 11.0 & 0.2 & $\mathrm{NS}$ \\
$\mathrm{Pi}(\mathrm{mg} / \mathrm{dL})$ & 5.6 & 6.0 & 0.4 & $\mathrm{NS}$ \\
$\mathrm{Mg}(\mathrm{mg} / \mathrm{dL})$ & 2.3 & 2.4 & 0.1 & $\mathrm{NS}$ \\
$\mathrm{Gla}-\mathrm{OC}(\mathrm{ng} / \mathrm{mL})$ & 106.3 & 103.0 & 8.6 & $\mathrm{NS}$ \\
$\mathrm{CT} \times(\mathrm{ng} / \mathrm{mL})$ & 1.2 & 1.6 & 0.1 & $\mathrm{NS}$ \\
\hline
\end{tabular}

$\mathrm{Na}$ : sodium, $\mathrm{K}$ : potassium, $\mathrm{Cl}$ : chlorine, $\mathrm{Pi}$ : inorganic phosphorus, $\mathrm{Ca}$ : calcium, Mg : magnesium, Gla-OC: Gla type osteocalcin, CTx : C-telopeptide fragments of type I collagen

NS : not significant

レージの嗜好性は，処理区間でほぼ同等であったと考えら れた，チモシーにおいては，DCAD 值を低くした場合で も，乾物摂取量には影響を及ぼさなかったという報告 (Penner 52008 ; Charbonneau 5 2009) がされてい
ることから, 塩素系肥料施用による粗飼料の DCAD 調整 が，啫好性に明らかな影響を及ぼす可能性は低いと考えら れた，乾物消化率においても，トウモロコシサイレージの DCAD 値の違いによる明らかな影響は認められなかった。 
尿中 $\mathrm{pH}$ は，体內の酸塩基平衡を示す指標として用いる ことができる. 飼料中の DCAD を低下させた場合, 血液の pHおよび尿中 pHが低下したという報告は多い) (Vagnoni と Oetzel 1998 ; Goff 52004 ; Heron 5 2009). 本試 験では高 DCAD 区と比較し，わずかではあるが低 DCAD 区で尿中 $\mathrm{pH}$ が有意に $(P<0.05)$ 低下していたことか ら，低 DCAD 区の牛で，体内の酸塩基平衡が酸性側に傾 いたと考えられた.

$\mathrm{K}, \mathrm{Na}$ および S 摂取量は，低 DCAD 区で高 DCAD 区 と比較し低くなったが，これはトウモ口コシサイレージの $\mathrm{K}, \mathrm{Na}$ および S 含量の違いおよびトウモロコシサイレ一 ジ摂取量の違いが影響したものと考えられた．また，両区 でK, Na および S 摂取量に有意な差は認められているが, 吸収量, 尿中または䔬中排泄量や体内での蓄積量には影響 を及ぼさなかった：このことから，これらの摂取量の違い は，体内の酸塩基平衡には大きな影響を及ぼさなかつたと 考えられた.

Cl 吸収量および尿中への Cl 排泄量は，低 DCAD 区で 高 DCAD 区と比較し高くなった. Horst と Jorgensen （1974）や Takagi と Block（1991）は，塩化アンモ二 ウムを添加した飼料を摂取したヤギやヒツジで，Cl 吸収 量および尿中への Cl 排泄量が有意に増加したことを報告 している. また, 粗飼料由来の Cl 摂取量が増加した場合, Cl 吸収量は増加したとの報告（Charbonneau 5 2009） があり，本試験も同様の結果となつた，腸管での Cl 吸収 率は，平均で 88\%程度とされており，摂取した Clの大半 が腸管内で吸収される（NRC 2001）。本試験における Cl 吸収率は，高 DCAD 区で 83.4\%，低 DCAD 区で 82.7\% であり, NRC (2001) の提示した平均値よりはやや低かつ たものの，摂取した Clの大半が消化管内で吸収され，体 内の酸塩基平衡に影響を及ぼしたと考えられた.

低 DCAD 飼料を摂取した場合，ウシは緩やかな代謝 性アシドーシスとなり，腸管での Ca 吸収の増加，骨から の Ca 放出, 腎臓での Ca 排泄量の増加などが起こると 報告されており（Block 1984 ; Schonewille 51994 ; Liesegang 2008)，これらが分娩時のCa 恒常性維持に 寄与するとされている (Horst 51997 ; Riond 2001). 本試験においては, 給与飼料中の DCAD 值を低下させた 時，尿中 Ca 排泄量のみが変化し，腸管での Ca 吸収量お よび蓄積量については，低 DCAD 区と高 DCAD 区の間 に明らかな違いは認められなかった. また, 骨代謝マ一カ一 に差が認められなかつたことから，本試験の DCAD 值の 違いは，骨代謝に明らかな影響を及ぼすしべルではなかつ たと考えられた。一方 Stacy とWilson（1970）は，ヒ ツジの血中に塩酸を投与すると 2 時間程度で尿中 Ca 濃度 の上昇が認められることから, 体内の酸塩基平衡の変化に 腎臓が速やかに反応し，Ca 再吸収が抑制されると示唆し ている. また BeckとWebster（1976）は，ラットを用 いた試験により，アシドーシスが直接，腎臓での Ca 再吸
収を抑制することを示唆している. これらのことから，低 $D C A D$ 区で尿中 C $\mathrm{a}$ 排泄量が増加した原因としては，低 DCAD トウモロコシサイレージ給与で CI 吸収量が増加 し, 体内の酸塩基平衡が酸性側に傾いたことにより, 腎臓 での Ca 再吸収がわずかに減少した可能性が考えられた

低 DCAD 区と高 DCAD 区において，K， Na，S，P お よび Mg の吸収率や血墏中濃度に差が認められなかつたこ とから, 高 Clトウモロコシサイレージの給与は, これら のミネラル恒常性に影響を及ぼさなかつたと考えられた。

飼料中の DCAD 値制御は，乳熱予防方法の一つとして 位置づけられており, 粗飼料中K含量が高いときなどには, 必要最低限のア二オン化した飼料の利用が必要であるとさ れている（日本飼養標準 2006 年版；農業・食品産業技術 総合研究機構 2006)。これまでの報告と同様に（Penner 52008 ; Heron 5 2009)，本試験においても施肥によ る粗飼料中 $\mathrm{Cl}$ 含量の増加は，体内の酸塩基平衡や尿中 Ca 排泄に影響を及ぼすことが示された。高 Cl 粗飼料は, 分娩前の飼料中 DCAD 調整に利用できると考えられた。

\section{謝辞}

本試験を遂行するにあたり，供試家畜の飼養管理および 試料採取に多大なご協力を頂いた九州沖縄農業研究セン 夕一研究支援センター業務第 1 科職員諸氏に深く感謝の 意を表します。本研究の一部はJSPS 科研費 26450386 の助成を受けたものです.

\section{文献}

Beck N. Webster SK. 1976. Effects of acute metabolic acidosis on parathyroid hormone action and calcium mobilization. American Journal of Physiology $\mathbf{2 3 0}$ 127-131.

Block E. 1984. Manipulating dietary anions and cations for prepartum dairy cows to reduce incidence of milk Fever. Journal of Dairy Science 67, 2939-2948.

Charbonneau E, Chouinard PY, Tremblay GF, Allard G. Pellerin D. 2009. Timothy silage with low dietary cation-anion difference fed to nonlactating cows. Journal of Dairy Science 92, 2067-2077.

Charbonneau E, Pellerin D, Oetzel GR. 2006. Impact of lowering dietary cation-anion difference in nonlactating dairy cows : A meta-analysis. Journal of Dairy Science 89, 537-548

Goff JP, Brummer EC, Henning SJ, Doorenbos RK, Horst RL. 2007. Effect of application of ammonium chloride and calcium chloride on alfalfa cation-anion content and yield. Journal of Dairy Science 90, 5159-5164.

Goff JP, Horst RL. 1997. Physiological changes at parturition and their relationship to metabolic disorders. Journal of Dairy Science 80, 1260-1268.

Goff JP, Ruiz R, Horst RL. 2004. Relative acidifying activity of anionic salts commonly used to prevent milk fever. Journal of Dairy Science 87, 1245-1255.

Gomori G. 1942. A modification of the colorimetric phosphorus determination for use with the photoelectric 
colorimeter. The Journal of Laboratory and Clinical Medicine 27, 955-960.

Heron VS, Tremblay GF, Oba M. 2009. Timothy hays differing in dietary cation-anion difference affect the capability of dairy cows to maintain their calcium homeostasis. Journal of Dairy Science 92, 238-246.

Horst RL, Goff JP, Reinhardt TA, Buxton DR. 1997. Strategies for preventing milk fever in dairy cattle. Journal of Dairy Science 80, 1269-1280.

Horst RL, Jorgensen NA. 1974. Effect of ammonium chloride on nitrogen and mineral balance in lactating and nonlactating goats. Journal of Dairy Science $\mathbf{5 7}$, 683-688.

伊藤秀文. 1975. 栽培植物分析測定法. pp. 76-86. 農林省農林 水産技術会議事務局監修. 養賢堂, 東京.

自給飼料利用研究会編. 2009. 三訂版粗飼料の品質評価ガイド ブック. 社団法人日本草地畜産種子協会, 東京.

Liesegang A. 2008. Influence of anionic salts on bone metabolism in periparturient dairy goats and sheep. Journal of Dairy Science 91, 2449-2460.

National Reseaich Council (NRC). 2001. Nutrient Requirements of Dairy Cattle. 7th. edn. National Academy Press, Washington DC.

農業·食品産業技術総合研究機構 編. 2006. 日本飼養標準 乳 牛. 2006 年版. 中央畜産会, 東京.

Pelletier S, Belanger G, Tremblay GF, Seguin P, Drapeau R, Allard G. 2007. Dietary cation-anion difference of Timothy (Phleumpratense L.) as influenced by appli- cation of chloride and nitrogen fertilizer. Grass and Forage Science 62, 66-77.

Penner GB, Tremblay GF, Dow T, Oba M. 2008. Timothy hay with a low dietary cation-anion difference improves calcium homeostasis in periparturient holstein cows. Journal of Dairy Science 91, 1959-1968.

Riond JL. 2001. Animal nutrition and acid-base balance. European Journal of Nutrition 40, 245-254.

SAS. 1999. SAS ${ }^{R}$ User's Guide : Statistics, version 8 edn. SAS Institute, Cary, NC.

Stacy BD, Wilson BW. 1970. Acidosis and hypercalciuria : Renal mechanisms affecting calcium, magnesium and sodium excretion in the sheep. The Journal of Physiology 210, 549-564.

佐藤義人, 芦田倫子, 村田憲昭. 2010. 施肥による牧草のイオン バランス制御。東北農業研究 63, 85-86.

Schonewille JTh, Van't Kloostera ATh H, Dirkzwager A, Beynen AC. 1994.Stimulatory effect of an anion (chloride) -rich ration on apparent calcium absorption in dairy cows. Livestock Production Science 40, 233240.

Takagi H, Block E. 1991. Effects of manipulating dietary cation-anion balance on macromineral balance in sheep. Journal of Dairy Science 74, 4202-4214.

Vagnoni DB, Oetzel GR. 1998. Effects of dietary cationanion difference on the acid-base status of dry cows. Journal of Dairy Science 81, 1643-1652.

\title{
The effects of chloride content in corn silage on mineral balance in dry cows
}

\author{
Yuko KAMIYA', Naoki KATO'1, Ikuo HATTORI', Itoko NONAKA'1 and Masahito TANAKA' \\ ${ }^{1}$ NARO Kyushu Okinawa Agricultural Research Center, Koshi 861-1192, Japan
}

Corresponding : Yuko KAMIYA (fax : +81 (0) 96-249-1002, e-mail : yukoiwm@affrc.go.jp)

The objective of this study was to evaluate the effect of low-DCAD corn silage with elevated chloride content on the mineral balance in dry cows. Corn grown at 2 locations was fertilized with either $\mathrm{KCl}$ or $\mathrm{NH}_{4} \mathrm{Cl}\left(\mathrm{Cl}\right.$ fertilization) or $\mathrm{K}_{2} \mathrm{SO}_{4}$ and $\left(\mathrm{NH}_{4}\right)_{2} \mathrm{SO}_{4}\left(\mathrm{SO}_{4}\right.$ fertilization). The $\mathrm{Cl}$ content of corn silage with $\mathrm{Cl}$ fertilizer (low-DCAD corn silage) was $5.3 \mathrm{~g} / \mathrm{kg}$ and that of corn silage with $\mathrm{SO}_{4}$ fertilizer (high-DCAD corn silage) was $3.5 \mathrm{~g} / \mathrm{kg}$. In a $2 \times 2$ crossover design, four non-pregnant dry Holstein cows were kept in individual tie stalls and fed either a high-DCAD corn silage diet (High-DCAD Group) or a low-DCAD corn silage diet (Low-DCAD Group). The intake and apparent absorption of $\mathrm{Cl}$ in the Low-DCAD Group were significantly $(P<0.01)$ higher than those in the High-DCAD Group. The intakes of $\mathrm{K}$, Na and $\mathrm{S}$ in the Low-DCAD Group were significantly lower than those in the High-DCAD Group. There were no significant differences in apparent absorption of $\mathrm{K}$, Na or $\mathrm{S}$ between the Low-DCAD Group and the High-DCAD Group. Urinary pH in the Low-DCAD Group was significantly lower than that in High-DCAD cows (8.06 vs. 8.22). Urinary Ca excretion in the Low-DCAD Group was significantly $(P<0.01)$ higher than that in the High-DCAD Group.

Nihon Chikusan Gakkaiho 86 (4), 449-455, 2015

Key words : chloride, corn silage, dietary cation-anion difference, dry cow, mineral balance. 